\author{
Contato \\ Rua Alberto Nascimento Jr, 178, bloco 1 - apto 102 \\ 05595-040 - São Paulo - SP \\ henrique.re@usp.br
}

\section{"MISSÃO NOS BRASIS": A BFASS E A ORGANIZAÇÃO DE UMA MISSÃO ABOLICIONISTA SECRETA AO BRASIL NO INÍCIO DA DÉCADA DE 1840}

\author{
Henrique Antonio Ré*
}

Universidade de São Paulo

São Paulo - São Paulo - Brasil

\title{
Resumo
}

Em 1839, a British and Foreign Anti-Slavery Society (BFASS) organizou veladamente uma missão para visitar o Brasil e, para realizá-la, contratou um casal britânico - George e Charlotte C. Pilkington - que deveria permanecer no país durante mais de um ano para coletar informações sobre o tráfico e a escravidão e fazer propaganda abolicionista. A partir de 1841, uma parte das informações obtidas por esta missão foi publicada pelo Anti-Slavery Reporter, o periódico oficial da Sociedade. No entanto, a BFASS ocultou por aproximadamente meio século seu envolvimento nesse empreendimento, que só se torna claro a partir do cruzamento de informações de várias fontes históricas.

\section{Palavras-chave}

Escravidão - tráfico de escravos - abolição - missão.

* Doutor em Sociologia pela Unicamp. Pós-doutorando no Departamento de História da Faculdade de Filosofia, Letras e Ciências Humanas. 


\section{Contact}

Rua Alberto Nascimento Jr, 178, bloco 1 - apto 102 05595-040 - São Paulo - SP henrique.re@usp.br
"MISSION TO BRAZILS": BFASS AND THE ORGANIZING OF A SECRET ABOLITIONIST MISSION TO BRAZIL IN THE EARLY 1840s

\section{Henrique Antonio Ré}

Universidade de São Paulo

São Paulo - São Paulo - Brasil

\section{Abstract}

In 1839, the British and Foreign Anti-Slavery Society (BFASS) covertly organized a mission to visit Brazil and, to achieve it, hired a British couple - George and Charlotte Pilkington - that should remain in the country for more than a year to collect information on trafficking and slavery and make abolitionist propaganda. From 1841, some of the information obtained by this mission was published by Anti-Slavery Reporter, the official journal of the Society. However, BFASS hid for about half a century his involvement in this venture, which only becomes clear from the crossing of information from various historical sources.

\section{Keywords}

Slavery - slave trade - abolition - mission. 


\section{Introdução}

Ao investigar as atuações clandestinas do movimento abolicionista britânico em outros países, o historiador David Eltis deparou-se com um documento intitulado "Missão nos Brasis". Este documento continha as instruções secretas que o casal George e Charlotte C. Pilkington deveria seguir durante sua estada no Brasil e foi assinado por J. H. Tredgold, o primeiro secretário da British and Foreign Anti-Slavery Society (BFASS).

Eltis também descobriu que o documento era de 1839 e que o casal permaneceu no Brasil durante o ano de 1840, desempenhando suas atribuições, tais como estipuladas no documento. A certeza de Eltis da efetividade da missão deveu-se ao seu conhecimento das cartas que o casal enviou do Brasil aos principais líderes da BFASS, e de um panfleto que George Pilkington publicou no Rio de Janeiro. Finalmente, Eltis chegou a expressar indignação com os termos do documento "Missão nos Brasis", pois, segundo ele, os abolicionistas não tolerariam tais atitudes caso fossem dirigidas à sua própria sociedade. ${ }^{2}$

Esse mesmo documento chamou a atenção de outros historiadores. Oliver Marshall, ao fazer um levantamento nos arquivos britânicos e irlandeses sobre materiais referentes ao Brasil, quando abordou a coleção da Anti-Slavery Society da Rhodes House Library, deu destaque a um documento que continha "várias cláusulas detalhadas referentes a um projeto de missão ao Brasil (sem data, mas provavelmente dos anos 1840) para investigar as condições dos escravos, dos negros livres e dos indígenas nativos".

Leslie Bethell e José Murilo de Carvalho também demonstraram interesse pelo documento, pois o citaram, ainda que de passagem, no livro em que abordaram a correspondência de Joaquim Nabuco com os abolicionistas britânicos: "nesse mesmo ano [1840], a nova Sociedade enviou uma

\footnotetext{
1 A tradução desse documento encontra-se no Apêndice ao final deste artigo.

2 Eltis também menciona que Pilkington pretendia obter um cargo oficial junto ao governo brasileiro, bem como estabelecer uma imprensa abolicionista. Essas informações não constam do documento "Missão nos Brasis". O historiador provavelmente retirou essas informações de uma carta que Pilkington enviou a algum integrante do Comitê da BFASS (não designado), datada de 25/03/1840. Cf. ELTIS, David. Economic growth and the end of the transatlantic slave trade. Nova York: Oxford University Press, 1989, p. 113 e 336, nota 49. Por último, o panfleto de Pilkington não foi publicado em 1844, como afirma Eltis, mas no início de 1841. Na verdade, Pilkington publicou três panfletos no Rio de Janeiro em 1841. Para os títulos completos, ver as referências bibliográficas neste artigo.

3 MARSHALL, Oliver. Brazil in British and Irish archives. $2^{\mathrm{a}}$ edição. Oxford: Centre for Brazilian Studies. University of Oxford, 2007, p. 218.
} 
missão secreta ao Brasil a fim de estudar a situação local. Não há informação sobre as consequências dessa missão, se houve alguma".

Não se trata aqui de afirmar que esses historiadores não conseguiram desvendar o episódio que envolveu a vinda da missão secreta patrocinada pela BFASS ao Brasil ou que tivessem qualquer pretensão nesse sentido. É inegável, no entanto, que o documento chamou-lhes a atenção, pois fizeram questão de mencioná-lo.

Mas, infelizmente, tal episódio permanece praticamente desconhecido da historiografia. David Eltis foi quem apresentou informações mais consistentes, contudo elas revelam muito pouco das atividades do casal Pilkington no Brasil e não explicam os motivos que coordenaram a organização da missão.

A razão desse desconhecimento e a dificuldade de se obter informação sobre esse episódio não são, entretanto, fortuitas. Em primeiro lugar, deve-se considerar o fato de que a missão era secreta e, como tal, a instituição que a organizou esforçou-se por mantê-la em sigilo mesmo depois que o casal Pilkington retornou à Inglaterra. Em segundo lugar, a missão só pode ser compreendida por meio do cruzamento de uma série de fontes, algumas britânicas, outras brasileiras.

O objetivo deste artigo é fazer esse cruzamento e apresentar ao leitor as principais circunstâncias que permitem esclarecer os propósitos da missão ao Brasil e alguns dos seus resultados.

\section{O documento "Missão nos Brasis"}

Este documento limita-se a instruir George Pilkington e sua esposa, Charlotte, sobre as atividades que deveriam desempenhar em sua visita ao Brasil, e a recomendar o sigilo requerido para sua realização. Embora não apresente nenhuma data, pode-se afirmar com toda certeza que o documento foi redigido em 1839. Ele não poderia ter sido elaborado antes, pois a fundação da BFASS ocorreu nesse ano. ${ }^{5}$ Tampouco poderia ter sido escrito posteriormente, pois, segundo uma carta de George Pilkington a J. H. Tredgold, datada do dia 10/12/1839, ele e Charlotte já haviam partido de Lon-

\footnotetext{
4 BETHELL, Leslie $\mathcal{E}$ CARVALHO, José Murilo de (org.). Joaquim Nabuco e os abolicionistas britânicos. Correspondência, 1880-1905. Rio de Janeiro: Topbooks, 2008, p. 26.

5 Os encontros que definiram a fundação da BFASS e o seu programa ocorreram em Londres, em 17 e 18 de abril de 1839. Cf. British and Foreign Anti-Slavery Society for the Abolition of Slavery and Slave-Trade throughout the World. Adress. Londres: Johnston and Barret, [1839], p. 1.
} 
dres e se encontravam em Liverpool à espera do navio que os conduziriam ao Brasil. Não foi possível saber a data exata em que o navio zarpou da Inglaterra, nem tampouco a do desembarque do casal na costa brasileira. Contudo, graças a uma carta de Charlotte a George William Alexander (o tesoureiro da BFASS), datada de 24/02/1840, ${ }^{6}$ é possível saber que o casal já se encontrava no Rio de Janeiro há aproximadamente duas semanas. Isso permite concluir que Pilkington e Charlotte provavelmente partiram da Inglaterra nos fins de dezembro de 1839 e chegaram ao Brasil nos primeiros dias de fevereiro de 1840.

As informações fornecidas pelo documento "Missão nos Brasis" são bastante restritas. De imediato, sabe-se que a BFASS contratou um casal para vir ao Brasil coletar informações sobre a situação da escravidão brasileira e do tráfico de escravos e levantar dados comerciais sobre o país, em especial sobre a produção de matérias-primas e os principais produtos importados. Havia um nítido interesse não só de estabelecer correspondentes que pudessem enviar periodicamente à BFASS relatos sobre a escravidão brasileira, como também de conseguir que algum representante brasileiro participasse do primeiro Congresso Abolicionista Mundial, ${ }^{7}$ patrocinado pela BFASS, a ser realizado em Londres, em meados de 1840. Tão importante quanto as atribuições do casal, era manter a missão em segredo e não associá-la à instituição que a patrocinava.

A rigor, somente pela leitura do documento, não se pode saber se a missão de fato chegou a se concretizar, pois, nitidamente, ele é uma espécie de contrato entre a BFASS e o casal. Todavia, pelo cruzamento de várias fontes documentais podem ser esclarecidos alguns aspectos da missão que, de fato, se efetivou, e desvendar as estratégias utilizadas pela BFASS para ocultá-la.

\footnotetext{
${ }_{6}^{6}$ Sobre as cartas de Pilkington e Charlotte às principais lideranças da BFASS, ver Rhodes House Library, Oxford, file G 79, British Empire, mss., S. 22.

7 Pilkington não conseguiu enviar informações relevantes sobre a situação da escravidão no Brasil a tempo de serem apresentadas no primeiro Congresso Abolicionista Mundial. Além disso, o Brasil não enviou nenhum representante, conforme o apêndice dos Proceedings, que contém a "Lista de membros". Cf. Proceedings of the General Anti-Slavery Convention, called by the Committee of the British and Foreign Anti-Slavery Society and held in London, from Friday, June $12^{\text {th }}$ to Tuesday, June 23rd 1840. Londres: British and Foreign Anti-Slavery Society, 1841.
} 


\section{A missão secreta e as estratégias da BFASS para ocultar o seu envolvimento}

A dificuldade para levantar os dados referentes à missão secreta dos Pilkingtons ao Brasil se deve ao fato de que a BFASS não mediu esforços para manter a missão sob sigilo total. Em momento algum essa instituição deixou pistas sobre sua participação na montagem e na execução do empreendimento. Ao contrário, breves menções explicativas tinham mais propriamente a intenção de lançar uma cortina de fumaça do que informar. Por isso mesmo, o documento "Missão nos Brasis" não foi publicado nem divulgado, e muito provavelmente só pôde ser consultado a partir do momento em que os arquivos da BFASS foram tombados em Oxford, pela Rhodes House Library. E esse mesmo caminho deve ter sido percorrido pelas cartas que Pilkington enviou do Brasil para a Inglaterra.

Desse modo, a única alternativa viável para desvendar esse episódio é o cruzamento das fontes produzidas pela missão com os materiais publicados pela BFASS ao longo dos anos, em especial pelo seu periódico, o Anti-Slavery Reporter. Pois, como foi mencionado acima, se alguém lesse qualquer conjunto desses textos separadamente - ou seja, somente o documento "Missão nos Brasis", ou somente as cartas provenientes do Brasil, ou então apenas o material publicado pelo Anti-Slavery Reporter, não conseguiria compreender o caráter da missão, as atividades dos Pilkington, ou a forma de coleta dos dados divulgados sobre o Brasil. Somente a partir de uma leitura integrada desse material é que se pôde compreender a organicidade do caso e construir uma narrativa dos eventos.

Entre março e julho de 1841, o Anti-Slavery Reporter publicou parte do material coletado por George Pilkington sob a forma de notícias e cartas anônimas. Depois disso, entre julho e dezembro do mesmo ano, publicou oito cartas assinadas por ele e também fez algumas menções aos panfletos abolicionistas lançados por um viajante no Rio de Janeiro, sem mencionar em momento algum qualquer ligação entre a BFASS e o autor dos panfletos.

Contudo, até hoje nada se sabe sobre o paradeiro dos originais dos relatos de Pilkington, que deveriam conter todos os resultados das suas investigações no Brasil. Aliás, a existência desses relatos é uma suposição levantada a partir do fato de que Pilkington deveria coletar uma quantidade considerável de informações sobre o Brasil, que só teria utilidade se fosse entregue por escrito. Contudo, há indícios de que ele entregou dois relatos à BFASS - um foi enviado por via postal, provavelmente no final de janeiro de 
1841, e outro teria sido entregue pessoalmente ao Comitê da Sociedade, no início de maio do mesmo ano, quando retornou à Inglaterra.

De todo modo, nada se sabe acerca dos resultados das suas investigações sobre a economia, a produção de matérias-primas e a população brasileira, e só é possível conhecer a parte das suas informações sobre a escravidão e o tráfico de escravos que foi publicada pelo Reporter. Muito provavelmente, ele coletou todas essas informações e as entregou à BFASS pelo simples e forte fato de que essa tarefa estava prescrita nas "instruções", um documento que tinha a força de um contrato de trabalho e que ele deveria cumprir à risca. Contudo, não interessou à Sociedade divulgá-las à época, e depois de mais de um século e meio não se tem notícia alguma sobre elas.

Além das oito cartas assinadas, o Reporter também publicou anteriormente cinco matérias anônimas sobre assuntos relativos à escravidão no Brasil, que certamente usaram informações passadas por Pilkington. Dessas cinco matérias, duas foram montadas com trechos dos relatos do agente alusivos às suas atividades, outras duas reproduzem textos (uma circular do governo brasileiro aos seus embaixadores e cônsules, e a introdução de uma reedição da Representação... de José Bonifácio) e uma se reduz à apresentação de uma lista de pessoas e de livros que se opunham à escravidão no Brasil.

A primeira delas veio a lume em 24 de março, e o seu assunto - medidas do governo brasileiro para promover a imigração de trabalhadores europeus - era um dos que Pilkington deveria investigar por determinação das "instruções". Assim sendo, uma coluna desse número do Reporter, intitulada "Informação colonial e estrangeira", reproduziu uma circular do Ministério dos Estrangeiros do Império do Brasil aos embaixadores e cônsules brasileiros da Europa sobre a necessidade de atrair imigrantes. ${ }^{8}$ E, segundo o Reporter, esta circular já havia sido publicada no Rio de Janeiro pelo Jornal do Commercio de 7 de janeiro de 1841, o que evidentemente quer dizer que o material foi traduzido para o inglês e remetido do Rio para Londres depois desta data.

Cerca de um mês depois, o Anti-Slavery Reporter publicou outra matéria sobre o tema - "Notas sobre o Brasil nas cartas de um viajante" 9 - e, de forma inusual, não fez nenhum comentário sobre essas "cartas" ou sobre o viajante e suas relações com a BFASS.

Essa matéria abrange três assuntos, e cada um deles tem um subtítulo. O primeiro, "Anedota sobre dois escravos fugitivos", identifica uma historieta

\footnotetext{
8 Anti-Slavery Reporter, 24 de março de 1841, p. 63.

9 Anti-Slavery Reporter, 21 de abril de 1841, p. 77-78.
} 
sobre como uma súplica cristã do autor ("Sede misericordiosos, como também vosso Pai é misericordioso") bastou para que um senhor de escravos de Minas não castigasse dois meias-caras que haviam tentado fugir. O segundo, "Mineração brasileira - a mina de Gongo Soco", nomeia um resumo de um texto de 10 páginas que registrava uma inspeção feita no poço desta mina pelo autor; este resumo destacava a diferença entre o trabalho insano a que estavam submetidos os escravos negros em oposição ao trabalho dos assalariados brancos. O terceiro, "Publicações abolicionistas colocadas em circulação no Brasil", apresenta, sem qualquer explicação, uma relação de títulos, as suas respectivas edições em inglês e em português e a tiragem de cada uma delas, a saber:

$\begin{array}{lr}\text { Carta aos residentes ingleses (em circulação) } & 1.200 \\ \text { Idem, em português (no prelo) } & 2.000 \\ \text { Em português, Testemunho de J. Scoble e de J. J. Gurney } & \\ \text { sobre os resultados da emancipação (em circulação) } & 2.000 \\ \text { Resposta a um padre católico romano } & 800 \\ \text { Idem, em português (no prelo) } & 1.200 \\ \text { Resposta a Filemon (em preparação) } & 1.000\end{array}$

Apesar do anonimato das "Notas...", não há dúvida alguma de que essa matéria foi montada com trechos de informações que George Pilkington enviara à BFASS sobre suas atividades no Brasil.

Os episódios narrados nos dois primeiros subtítulos se referem a Minas, e Pilkington visitara a província principalmente para investigar a condição dos escravos das companhias inglesas de mineração. ${ }^{10}$ Finalmente, quanto às "publicações", esses títulos são grosso modo os dos panfletos que Pilkington lançara no início de 1841.

O que importa nessas notícias é que Pilkington não só informava à BFASS sobre as suas investigações no Brasil como também sobre o lançamento dos panfletos, tanto que os títulos dessa lista e os títulos dos panfletos publicados são semelhantes, embora não sejam exatamente os mesmos. E, como se vê nessa relação, dois panfletos ainda estavam no prelo quando a BFASS recebeu o material, o que mais uma vez sugere que o material foi

\footnotetext{
${ }^{10}$ A anedota sobre os dois escravos foi montada a partir da descrição do episódio enviada por Pilkington, em carta datada de 21/08/1840.
} 
enviado para a Inglaterra no começo de 1841. E o último folheto da lista, que estava "em preparação", não chegou a ser publicado.

A próxima matéria do Reporter composta com material enviado por Pilkington intitulava-se "Sentimento no Brasil",11 e tinha como assunto a crítica à escravidão feita pelo "falecido José Bonifácio de Andrada e Silva", e o sentimento abolicionista no país era um dos assuntos que as "instruções" determinavam que Pilkington deveria investigar. As poucas linhas usadas para apresentar José Bonifácio descrevem-no como "patriarca da independência brasileira, irmão de dois dos atuais ministros e autor de uma memória contra a escravidão, que foi reeditada recentemente com uma introdução". A matéria propriamente dita é formada pela introdução anônima dessa reedição da Representação... vertida para o inglês; e a justificativa usada para publicá-la é a de que o texto expunha a "energia e a promessa do curso dos sentimentos abolicionistas no Brasil".

Quanto ao texto da introdução da Representação..., o que mais chama a atenção é que o meio sugerido para pôr fim ao tráfico negreiro era exatamente o mesmo adotado pela BFASS para suprimir tanto o tráfico quanto a escravidão: "o principal meio a empregar para tão grande fim é a persuasão, e muito se terá feito se o preconceito favorável à introdução da escravatura no Brasil for substituído por ideias mais sãs e judiciosas a este respeito".12 Mas não há indício algum de que a BFASS ou George Pilkington tivessem tido algo a ver com essa introdução e a reedição da Representação.

De qualquer maneira, o "Sentimento no Brasil" foi a última matéria construída com um texto que George Pilkington havia enviado do Brasil à BFASS. E ela foi publicada poucos dias antes do regresso do agente à Inglaterra, ou então quando ele já estava em solo britânico, pois Pilkington havia partido do Rio de Janeiro nos fins de março.

Ao regressar à Inglaterra, Pilkington provavelmente entregou à BFASS o restante das informações coletadas no Brasil. Contudo, antes que qualquer artigo fosse extraído desse material recém-chegado, o Reporter trouxe novamente à baila a "missão nos Brasis" em um dos itens do "Relatório da Sociedade Abolicionista Britânica e Estrangeira do ano de 1841",13 - "Operações no Exterior", que lista as diversas atividades internacionais da Sociedade.

\footnotetext{
11 Anti-Slavery Reporter, 21 de abril de 1841, p. 78-79.

12 SILVA, José Bonifácio de Andrada e. Representação à Assemblea Geral Constituinte e Legislativa do Império do Brasil, sobre a escravatura. Rio de Janeiro: Typographia de J. E. S. Cabral, 1840, p. III-IV.

13 Anti-Slavery Reporter, 2 de junho de 1841, p. 123.
} 
O Brasil ocupa apenas dois parágrafos nesse item. O primeiro se refere aos avanços da oposição à escravidão no Brasil e dá destaque a uma medida do governo que havia interditado o emprego de escravos nas obras públicas; o segundo explica que "um amigo" da BFASS esteve durante "alguns meses" no Brasil "para colher informações sobre a escravidão e sobre o tráfico", que seriam divulgadas no momento oportuno; informa também que ele redigiu e lançou no Rio de Janeiro mais de 8.000 panfletos "em português e em inglês" sobre os "males da escravidão e os [bons] resultados da emancipação nas colônias britânicas". Desse modo, uma mensagem truncada do Reporter noticiava que o periódico começaria a publicar o restante das informações coletadas na "missão nos Brasis".

O que há de mais importante nessa mensagem é que a BFASS deixava subentendido que Pilkington viajara para o Brasil, lançara panfletos e coletara essas informações por conta própria; e, mesmo assim, não menciona o seu nome, que é substituído por "um amigo", querendo com isso dizer que se tratava de um simpatizante que não pertencia aos quadros da Sociedade. E é impossível deixar de associar o emprego da palavra "amigo" nesse texto com o emprego dela mesma no documento "Missão nos Brasis". Com efeito, nas quatro páginas originais desse documento há apenas uma única referência nas suas primeiras linhas ao nome de George Pilkington; daí em diante, o nome do agente é substituído por "amigo", que estava sujeito a uma "regra inviolável": não poderia revelar quais são as "suas conexões com esta instituição, ou qual é o objetivo particular da visita aos Brasis".

No seu número seguinte, o Anti-Slavery Reporter publicou uma matéria intitulada "Brasil",14 montada, segundo o editor, com excertos de "cartas recentes", "enviadas por um cavalheiro que está no Rio de Janeiro" e que permitiu que o periódico as publicasse.

Os assuntos dos excertos eram: maus-tratos de escravas por uma companhia inglesa de mineração de Minas, publicação de panfletos, queda do "Gabinete da Maioridade" e conivência dos poderes constituídos do Império do Brasil com a continuidade do tráfico, a despeito dos acordos do governo brasileiro com a Inglaterra para suprimi-lo.

No seu número seguinte, o Reporter publicou outra matéria que utilizava resultados das investigações de Pilkington no Brasil, intitulada "Sentimento abolicionista no Brasil".15 Desta vez, trata-se de uma lista de "pessoas distin-

\footnotetext{
${ }^{14}$ Anti-Slavery Reporter, 16 de junho de 1841, p.131.

${ }^{15}$ Anti-Slavery Reporter, 30 de junho de 1841 p. 138.
} 
tas do Brasil que são contrárias à escravidão" e de "obras" antiescravistas que "foram publicadas por brasileiros e que são vendidas livremente no Rio de Janeiro" e da libertação de escravos por cidadãos.

A lista de "pessoas distintas" traz os nomes de sete políticos com uma curta descrição das suas propostas antiescravistas, a saber: Antônio Pereira França, Antônio Carlos e Martim Francisco Andrada e Silva, Holanda Cavalcanti, Aureliano Coutinho, Montezuma e Cândido Batista de Oliveira. A lista de "obras" alude ao "plano de emancipação" de José Bonifácio, a um "trabalho que faz uma censura rigorosa ao tráfico e à escravidão", de autoria do major Burlamaqui, e a dois artigos publicados no periódico do Instituto Histórico e Geográfico do Brasil pelo rev. Januário da Cunha Barbosa e por José Silvestre Rebello. ${ }^{16}$

Quanto à libertação de escravos, a matéria narra que a Grande Loja Maçônica do Rio de Janeiro comprou e alforriou alguns escravos no dia de São João, e as "revoltas da Bahia e do Rio Grande do Sul" emanciparam os escravos. A última revolta ainda não havia sido debelada, e o artigo expunha a situação: "um grupo [de escravos] muito poderoso (fisicamente falando) se alistou sob as bandeiras dos descontentes, o que é uma lição impressionante ensinada aos que estavam no poder, e se espera que eles não sejam muito cegos a ponto de nada aprender".

E, em contraste com isso tudo, a matéria lembrava que a Lei de 1831 considerava livres todos os africanos que desembarcassem no Brasil; contudo, "o número de negros que foram clandestinamente introduzidos [depois de 1831] no Brasil, deve chegar, no mais baixo dos cômputos, a 300.000!"

Essa foi a última matéria anônima do Reporter composta com material dos relatos da "missão nos Brasis". Cerca de um mês depois, em 28 de julho de 1841, o periódico publicou a primeira carta assinada por George Pilkington. E, na página subsequente à dessa carta, há um editorial ${ }^{17}$ que explica que ela era a primeira de uma série de cartas escritas pelo "sr. Pilkington, que voltou recentemente" do Brasil, para onde viajara com o objetivo de "coletar fatos acerca da escravidão e do tráfico neste país".

A partir dessa data e até 1 de dezembro de 1841, o Reporter publicou uma série de oito cartas sobre a escravidão no Brasil assinadas por George Pilkington e datadas como se tivessem sido escritas poucos dias antes da publica-

\footnotetext{
${ }^{16}$ Estes artigos foram publicados no tomo I, n. 3 ( $3^{\circ}$ sem. 1839) da Revista do Instituto Historico e Geographico do Brazil, p. 123-133.

${ }^{17}$ Anti-Slavery Reporter, 28 de julho de 1841, p. 165.
} 
ção. E, dessa forma, a BFASS continuava a ocultar o seu papel de promotora e de executora da "missão nos Brasis".

Em resumo, de março a julho de 1841, a BFASS publicou as informações enviadas por Pilkington como matérias anônimas do Reporter. A partir de então, depois de ter examinado o restante das informações que Pilkington entregara para encerrar sua prestação de contas da missão, o Comitê resolveu que só seria publicado o material referente à escravidão; assim, ordenou ao seu agente que o transformasse em cartas assinadas, e deu-lhes datas próximas às datas em que elas sairiam no periódico.

Desse modo, pôde atribuir de uma só vez à iniciativa do próprio George Pilkington a ida ao Brasil, o lançamento de panfletos abolicionistas no Rio de Janeiro e o envio de cartas ao Reporter sobre a escravidão no país.

Os panfletos alicerçaram essa estratégia de ocultação da missão. Como eles haviam sido publicados no início de 1841 pela Editora Laemmert do Rio de Janeiro e estampavam a autoria de George Pilkington nas suas capas, ficou fácil para a BFASS lançar à responsabilidade pessoal do seu agente a viagem ao Brasil, a sua ação abolicionista neste país e o abolicionismo das suas cartas publicadas no segundo semestre de 1841. Além disso, o abolicionismo exposto nos panfletos relacionava-se com fatos da escravidão no Brasil apresentados nas cartas; desse modo, no conjunto, os assuntos dos panfletos e das cartas se completavam, evidenciando que foram escritos pelo mesmo autor.

George Pilkington não tinha nada a perder com isso tudo, pois o governo brasileiro não criaria uma questão diplomática por causa das opiniões de um cidadão britânico sobre a escravidão no país. Por outro lado, Pilkington ganhou alguma notoriedade nos círculos abolicionistas, tanto que participou do segundo Congresso Abolicionista Mundial em 1843 na condição de correspondente da BFASS ${ }^{18}$ e foi um dos indicados para preparar o esboço do memorial do Congresso, que o Comitê da BFASS dirigiria "ao povo e ao governo do Brasil".19

Se uma parte do relato de Pilkington foi divulgada pelo Reporter, os seus panfletos não tiveram a mesma sorte. A BFASS só revelou com todas as letras que eram de autoria de George Pilkington e expôs em poucas linhas

\footnotetext{
${ }^{18}$ Proceedings of the General Anti-Slavery Convention, called by the Committee of the British and Foreign Anti-Slavery Society and held in London, from Tuesday, June $13^{\text {th }}$ to Tuesday, June $20^{\text {th }} 1843$. Londres: British and Foreign Anti-Slavery Society, 1843, p. 346. Esta mesma informação aparece no Anti-Slavery Reporter de 21 de junho de 1843, p. 104.

19 Proceedings of the General Anti-Slavery Convention... 1843, op.cit., p. 296.
} 
o assunto de cada um deles mais de um ano depois do regresso do autor à Inglaterra no seu Terceiro Relatório Anual, publicado em 13 de maio de 1842.. Na apresentação das "Operações no exterior" da Sociedade há uma página dedicada aos "Brasis" que menciona a viagem de Pilkington ao Brasil e as informações que obteve sobre o "sistema da escravidão" no país; além disso, também mencionava que:

Durante a sua estada nos Brasis, o sr. e a sra. Pilkington fizeram circular centenas de publicações abolicionistas e tiveram um papel determinante ao despertar um profundo interesse nas almas de muitas pessoas sobre a condição do escravo. ${ }^{21}$

Mais adiante, um item denominado "Delegação ao Brasil" desenvolve o conteúdo dessa apresentação em quatro páginas que resumem as cartas assinadas por Pilkington e acrescentam o seguinte comentário: pouco antes de voltar à Inglaterra, depois de ter percorrido as "províncias do nordeste do Brasil", George Pilkington sentiu que era seu dever "protestar contra os males que havia testemunhado". Por isso, publicou 9.200 panfletos no Rio de Janeiro:

“Carta aos ingleses residentes no Brasil", com duas mil cópias em inglês e mil e duzentas em português [...] Essa "Carta" induziu um padre irlandês a escrever ao sr. Pilkington que por isso escreveu uma réplica, na qual acusa a Igreja brasileira de ter escravos e de ser conivente com a ilicitude do tráfico negreiro; ele publicou e pôs em circulação dois mil exemplares em inglês e a mesma quantidade em português dessa "Réplica". Um terceiro panfleto, que demonstra as vantagens do trabalho livre depois da emancipação nas Índias Ocidentais com "extratos das cartas de Joseph John Gurney e de discursos de John Scoble", também foi publicado, e dois mil exemplares tiveram ampla circulação.22

Além de se referir aos panfletos, esse Relatório é importante na história da divulgação dos resultados da "Missão nos Brasis" porque exibe a cautela da BFASS para expor o seu papel na idealização e na execução da missão. Com efeito, a apresentação citada acima se inicia com a seguinte afirmação:

Por sugestão de diversos amigos devotados da Sociedade, o sr. e a sra. Pilkington viajaram aos Brasis por volta dos fins de 1839 para fazer uma investigação sobre vários objetos

\footnotetext{
${ }^{20}$ Este Relatório também foi publicado pelo Anti-Slavery Reporter de 18 de maio de 1842, p. 73-76.

${ }^{21}$ The Third Annual Report of the British and Foreign Anti-Slavery Society for the Abolition of Slavery and the Slave-Trade throughout the World; presented to the General Meeting held in Exeter Hall, on Friday, May 13 $3^{\text {th }}$, 1842. Londres: Printed for the Society, 1842, p. 30.

${ }^{22}$ The Third Annual Report.., op. cit., p. 150.
} 
relacionados com o sistema da escravidão existente naquele país e sobre a dimensão e o caráter do tráfico. ${ }^{23}$

Na verdade, a BFASS jamais expôs claramente que havia promovido a missão e esse texto exibe o mais alto grau da exposição pública do seu envolvimento com ela: a viagem do casal ao Brasil e as suas investigações sobre a escravidão no país decorreram de uma "sugestão de diversos amigos devotados da Sociedade".

A partir de 1843, a "missão nos Brasis" desapareceu das páginas do Anti-Slavery Reporter, iniciando aparentemente a sua jornada rumo ao esquecimento. Todavia, em 1849, numa notícia em que abordava a utilização de escravos pelas companhias mineradoras britânicas que atuavam no Brasil, a BFASS afirmou que "dez anos atrás, a Sociedade Abolicionista enviou um agente ao Brasil com a finalidade de investigar, entre outras coisas, a condição dos escravos empregados pelas companhias britânicas de mineração no país". ${ }^{24}$

Além dessa informação, a notícia ainda reproduzia os dados, colhidos por esse agente, a respeito dos escravos pertencentes a cada companhia. ${ }^{25}$ Reproduzia também trechos da terceira carta assinada por Pilkington e publicada pelo Reporter. ${ }^{26}$ Mas, em momento algum, a notícia esclareceu quem foi esse agente e de onde foram extraídas as passagens mencionadas. De todo modo, essa foi a primeira vez que a BFASS assumiu claramente que enviou um agente ao Brasil, porém ocultou suas verdadeiras atribuições, alegando que tal agente fora incumbido de investigar a condição dos escravos das companhias britânicas de mineração.

Nos últimos anos de vida da BFASS, o periódico voltou a se referir parcialmente ao assunto da "Missão" em uma lista das suas grandes realizações, feita para fins de memória da Sociedade. De fato, o Reporter de novembro/dezembro de 1897, traz um "Breve sumário dos principais trabalhos da Sociedade Abolicionista Britânica e Estrangeira" onde se lê que, entre os feitos da Sociedade em "1840" (sic) estavam os "8.000 panfletos postos em circulação

\footnotetext{
${ }^{25}$ The Third Annual Report..., op. cit., p. 30.

${ }^{24}$ Anti-Slavery Reporter, 1 de novembro de 1849, p. 168.

${ }^{25}$ Os dados apresentados na notícia de 1849 reproduzem quase fielmente os enviados por Pilkington na sua carta de 17/09/1840.

26 Anti-Slavery Reporter, 25 de agosto de 1841, p. 179-80.
} 
no Brasil". ${ }^{27}$ E, em 1901, um Sumário cronológico da obra da Sociedade Abolicionista Britânica e Estrangeira no século XIX reproduziu essa mesma informação. ${ }^{28}$

Em 1909, a BFASS fundiu-se com a Sociedade de Proteção aos Aborígenes, que passou a se chamar Sociedade Abolicionista e de Proteção aos Aborígenes. John Harris, um dos seus secretários, publicou um livro destinado à edificação da memória do abolicionismo britânico, e nele também se referiu aos 8.000 panfletos lançados no Brasil em "1840" (sic) "pela Sociedade Britânica" (sic), que "tiveram muito apoio local". ${ }^{29}$

Portanto, ainda que em 1849 a BFASS tenha assumido que enviou um agente ao Brasil dez anos antes para investigar a condição dos escravos das companhias mineradoras britânicas, a natureza das atividades desse agente, a sua identidade e os desdobramentos da missão só poderiam ser esclarecidos por meio do cruzamento das citações contidas nessa notícia com a carta que Pilkington publicou no Reporter. Ou seja, mais uma vez a BFASS não se expôs integralmente e nem explicitou quais os verdadeiros motivos de ter enviado uma missão ao Brasil.

Enfim, considerando que os panfletos foram lançados em 1841, a BFASS demorou mais de meio século para manifestar publicamente que lançara panfletos abolicionistas e que esteve diretamente envolvida com a vinda da missão secreta de George e Charlotte Pilkington ao Brasil. Mas, nessa época e da forma como o assunto foi tratado, dificilmente algum leitor poderia saber efetivamente do que estava em questão.

Embora a descrição das estratégias da BFASS para esconder o seu patrocínio e envolvimento com a missão do casal Pilkington ao Brasil tenha assumido uma forma quase detetivesca, ela foi necessária para explicitar as dificuldades geradas pelas informações falsas veiculadas principalmente pelo Anti-Slavery Reporter tanto a respeito dos períodos em que Pilkington esteve no Brasil quanto sobre a forma como as informações foram obtidas.

\section{A internacionalização do movimento abolicionista britânico}

A missão do casal Pilkington ao Brasil não deve ser compreendida como um evento isolado, fruto da impaciência dos abolicionistas britânicos que,

\footnotetext{
${ }^{27}$ Anti-Slavery Reporter, novembro/dezembro de 1897, p. 288.

${ }^{28}$ A Chronological Summary of the Work of the British $\mathcal{E}$ Foreign Anti-Slavery Society during the nineteenth century (1839-1900). Londres: Offices of the Society, 1901, p. 2.

${ }^{29}$ HARRIS, John. A century of emancipation. Londres: Kennikat Press, 1971 [original de 1933], p. 102.
} 
num determinado momento, teriam decidido atuar diretamente nas sociedades escravistas. A própria BFASS, instituição que organizou a missão, se autointitulava "britânica e estrangeira", numa clara alusão às suas pretensas atividades no exterior.

Ademais, com a aprovação da abolição da escravidão nas Índias Ocidentais britânicas ${ }^{30}$ em 1833, e com o fim do período de aprendizado em 1838, apenas restou aos abolicionistas britânicos a possibilidade de criticar as indenizações aos fazendeiros, aprovadas pelo Parlamento, e manter certa vigilância em relação às medidas que poderiam ser adotadas individualmente pelas colônias britânicas para forçar os libertos a trabalhar nas plantations.

Mas se, por um lado, a vitória doméstica se afigurou praticamente completa, por outro, também lançou uma dúvida enorme entre os abolicionistas. Uma vez conquistados os objetivos em relação às Índias Ocidentais, o que fazer doravante? Seria o momento de desmontar toda a estrutura organizacional que levou décadas para ser formada ou seria a ocasião de ampliar a luta abolicionista para o estrangeiro?

De certo modo, essa pergunta já havia começado a receber uma resposta em 1834, quando o Comitê de Ação, que era um desdobramento da Sociedade Abolicionista (1831-35?) mudou seu nome para The Society for the Universal Abolition of Slavery and the Slave Trade (Sociedade para a Abolição Universal da Escravidão e do Tráfico de Escravos). ${ }^{31}$ Essa entidade teve uma duração efêmera e logo se extinguiu, provavelmente como reflexo das divergências no interior das fileiras abolicionistas a respeito dos rumos que deveriam ser conferidos ao movimento. Mas o grande sucesso conquistado com o fim do aprendizado encorajou os abolicionistas a definir alvos maiores. O objetivo agora era abolir a escravidão no mundo todo. E o principal alvo eram os Estados Unidos, seguidos por Brasil e Cuba, onde o tráfico florescia apesar dos tratados que o tornavam ilegal. ${ }^{32}$ Não à toa, neste momento,

\footnotetext{
30 “A Lei de 1833 foi, de fato, aplicada em apenas quatro áreas: Índias Ocidentais, Ilhas Maurício, Canadá (onde a escravidão já havia praticamente desaparecido graças à legislação local), e ao Cabo da Boa Esperança. Em outros locais das possessões britânicas e, mais especificamente, na Índia e no Ceilão, a escravidão continuou a florescer em suas várias formas, numa escala tão grande que, somente por meio de uma estimativa aproximada, se poderia conhecer o número de escravos realmente existentes." Cf. TEMPERLEY, Howard. British antislavery, 1833-1870. Columbia: University of South Carolina Press, 1972, p. 93.

${ }^{31}$ Sigo a descrição de TEMPERLEY, Howard. British antislavery, op. cit., p. XII e segs.

32 MURRAY, David. Odious commerce. Britain, Spain and the abolition of the Cuban slave trade. Cambridge: Cambridge University Press, 1980, p. 133.
} 
os abolicionistas adotaram como um de seus dísticos preferidos: "Meu país é o mundo e meus compatriotas são a humanidade". 33

Portanto, nos anos imediatamente posteriores ao final da escravidão nas Índias Ocidentais britânicas ocorre uma reestruturação das instituições abolicionistas na Grã-Bretanha. Temperley aponta que surgiram duas opções, por ele denominadas de "Solução de Buxton" e "Solução de Sturge".

A primeira delas foi capitaneada por Thomas Fowell Buxton e se estruturou a partir da criação da Society for the Extinction of the Slave Trade and for the Civilization of Africa (Sociedade para a Extinção do Tráfico de Escravos e para a Civilização da África), que durou de 1839 a 1843. Para os propósitos deste trabalho, esta "solução" não nos interessa, pois consistia na intervenção direta na África, com o intuito de criar fazendas-modelo, capazes de se tornar exemplos para os africanos, de modo que o tráfico de escravos fosse substituído pelas atividades agrícolas e, consequentemente, pelo comércio legítimo que tais atividades promoveriam. ${ }^{34}$

A "Solução de Sturge", referência ao quacre Joseph Sturge, o principal responsável pela criação da BFASS, em 1839, consistia em combater o tráfico de escravos e a escravidão no mundo por meios totalmente pacíficos. Isso se daria de inúmeras formas, mas principalmente pela mobilização da sociedade civil britânica e pela pressão política junto aos membros parlamentares, quer por petições enviadas por entidades abolicionistas, chamadas de auxiliares, quer pela atuação direta de parlamentares comprometidos com a causa. Obviamente, em relação às sociedades escravistas, a BFASS pretendia reproduzir a sua forma de atuação, incentivando a criação e difusão de entidades com características semelhantes.

É preciso salientar que a BFASS era uma entidade da sociedade civil, mantida por meio de subscrições. Todavia, essas subscrições eram insuficientes para honrar todos os seus compromissos. A BFASS era, desse modo, socorrida financeiramente pelos seus principais dirigentes, que lhe

\footnotetext{
33 TAYLOR, Clare. British and American abolitionists. Edinburgh: Edinburgh University Press, 1974, p. 1. The Liberator, o jornal abolicionista editado por Garrison nos Estados Unidos, até utilizava essa frase como cabeçalho. Cf. TEMPERLEY, Howard. British antislavery, op. cit., p. 20.

${ }^{34}$ Para uma apreciação das principais propostas de Buxton, ver BUXTON, Thomas Fowell. The African slave trade and its remedy. $2^{\mathrm{a}}$ edição. Londres: John Murray, 1840, especialmente as páginas 518-22. Para conhecer a expedição malograda, organizada por Buxton, com o objetivo de fundar colônias agrícolas na África, ver TEMPERLEY, Howard. White dreams, black Africa. The antislavery expedition to the river Niger, 1841-1842. New Haven; Londres: Yale University Press, 1991; ver também GALLAGHER, J. Fowell Buxton and the new African policy, 1838-1842. Cambridge Historical Journal, v. 10, n. 1, 1950, p. 36-58.
} 
doavam vultosas quantias. Seu tesoureiro, G. W. Alexander, também era o banqueiro da instituição e, em vários momentos de déficit, permitiu que ela trabalhasse com um saldo devedor superior a $£ 500 .^{35}$ Esses dirigentes eram em sua maioria quacres, que acabaram impondo diretrizes pacifistas à atuação da sociedade, nem sempre endossadas pelos demais grupos.

Porém, o que mais nos importa na fundação da BFASS é o seu objetivo principal. E o segundo artigo da sua declaração de fundação era bem preciso: "Os objetivos desta Sociedade serão a extinção universal da escravidão e do tráfico...".36

Numa inversão da estratégia abolicionista do início do século, que centralizava suas ações no combate ao tráfico, Sturge propunha agora o combate direto também à própria escravidão. O terceiro artigo da declaração de fundação explicitava o motivo dessa inversão: "com a existência da escravidão, não há perspectiva razoável para a supressão do tráfico e para a eliminação da venda e dos negócios com seres humanos". A famosa frase cunhada por Thomas Clarkson, um dos maiores expoentes do abolicionismo britânico do início do século XIX, quando os abolicionistas conseguiram obter do Parlamento a abolição do tráfico, "eles [os abolicionistas] deitaram o machado diretamente à raiz", ${ }^{37}$ agora era invertida por Sturge: deitar o machado à raiz significava combater a escravidão, pois enquanto ela existisse, o tráfico não cessaria.

O quarto artigo da declaração de fundação indicava como outro objetivo da BFASS a divulgação de "informações corretas" a respeito do escravismo. Desse modo, tanto para lutar contra a escravidão no mundo quanto para atender às exigências presentes em sua própria declaração de fundação, a BFASS necessitava obter informações precisas a respeito da escravidão e do tráfico de escravos nos países que ainda adotavam tais práticas.

Nesse sentido, o Comitê da BFASS enviou para vários países, onde podia contar com correspondentes ou colaboradores, uma série de questões sobre a situação do tráfico de escravos e da própria escravidão. Nas Américas, excetuando o sistema escravista francês, já em declínio, e algumas ilhas coloniais europeias de pouca expressão, ainda havia três grandes sistemas escravistas: o sul dos Estados Unidos, Cuba e Brasil, todos em franca expan-

\footnotetext{
35 TEMPERLEY, Howard. British antislavery, op. cit., p. 82.

${ }^{36}$ British and Foreign Anti-Slavery Society for the Abolition of Slavery and Slave-Trade throughout the World. Londres: Johnston and Barrett, s.d. [1939?], p. 1.

37 CLARKSON, Thomas. History of the rise, progress and accomplishment of the abolition of the African slave trade by the British Parliament. $1^{\text {a }}$ ed. Londres: Longman, 1808, v. 1, p. 286.
} 
são. ${ }^{38}$ Dos Estados Unidos, que já contava com um movimento abolicionista organizado, o Comitê recebeu as respostas ao questionário, posteriormente publicadas em livro. ${ }^{39}$ Sobre o Brasil e Cuba não há informações de que tenham chegado a BFASS as respostas ao questionário nem que ele tenha sido de fato enviado a esses países. ${ }^{40}$

Em relação especificamente ao Brasil, a BFASS procurou contornar o problema da falta de informações por meio do envio da missão secreta dos Pilkington. Não foram somente os navios britânicos, as canhoneiras ou os cônsules de sua majestade que atuaram e pressionaram o país para encerrar o tráfico e combater a escravidão. Da Grã-Bretanha também chegaram missões abolicionistas pacifistas ${ }^{41}$ e junto com elas um conjunto de ideias humanitárias e estratégias de atuação, sempre balizadas pelos marcos ideológicos da sociedade burguesa.

\section{A experiência abolicionista britânica no exterior}

Nas primeiras décadas do século XIX, o movimento abolicionista britânico já possuía longa experiência de atuação junto a sociedades escravistas, quer do próprio Império britânico, quer de outras nações. A historiografia há muito registra o envolvimento e a troca de experiências abolicionistas ou antiescravistas entre os dois lados do Atlântico. Desde o século XVII, principalmente entre os quacres, mas, posteriormente, entre batistas e metodistas

\footnotetext{
${ }^{38}$ Esses três sistemas escravistas foram o resultado da crescente demanda europeia por produtos tropicais e da especialização internacional da produção de alimentos e matérias-primas, e são os melhores representantes daquilo que Dale Tomich chamou de "segunda escravidão". Cf. TOMICH, Dale. Pelo prisma da escravidão. Trabalho, capital e economia mundial. São Paulo: Edusp, 2011, p. 86-7.

${ }^{39}$ Ver Slavery and the internal slave trade in the United States of North America; Being replies to questions transmitted by the Committee of the British and Foreign Anti-Slavery Society, for the abolition of slavery and the slave trade throughout the World... Londres: Thomas Ward and Co., 1841.

${ }^{40}$ Em relação a Cuba, a BFASS já dispunha de informações graças a David Turnbull, que visitou o Caribe entre 1837-39 e passou os dois últimos anos na ilha espanhola. Turnbull escreveu em 1840 o livro Travels in the West, no qual apresentou suas investigações, além de um plano para tornar instável a propriedade dos escravos importados ilegalmente para Cuba e também para o Brasil. No mesmo ano, Turnbull apresentou esse mesmo plano no primeiro Congresso Abolicionista Mundial. Deste modo, pode-se dizer que com o preenchimento do questionário pelos abolicionistas norte-americanos e com as informações de Turnbull sobre Cuba, das três maiores sociedades escravistas das Américas, a BFASS só não dispunha de informações confiáveis do Brasil. Ver TURNBULL, David. Travels in the West: Cuba; with notices of Porto Rico and the slave trade. Londres: Longman, Orme, Brown, Green, and Longmans, 1840.

${ }^{41}$ Além da missão organizada pela BFASS, a Religious Society of the Friends of Great Britain and Ireland também organizou uma missão ao Brasil no início da década de 1850.
} 
houve um intenso intercâmbio entre os britânicos e os colonos das Índias Ocidentais e das colônias norte-americanas. ${ }^{42}$ Contudo, é necessário salientar que esse intercâmbio, embora produzisse resultados efetivos em círculos locais, era restrito a pequenos grupos, em geral de religiosos.

Somente no final do século XVIII e início do XIX, quando, de fato, o movimento abolicionista britânico torna-se um movimento político, tem início uma troca efetiva de experiências entre os abolicionistas. Após a abolição do tráfico britânico e norte-americano, em 1807, e com o esforço do estado britânico junto às demais potências coloniais europeias e às recentes nações americanas para o estabelecimento de tratados contra o tráfico de escravos, abriu-se uma enorme possibilidade de correspondência entre grupos abolicionistas organizados ou mesmo indivíduos que de algum modo atuavam isoladamente. Esse é o momento que Richard Huzzey chamou de passagem de "uma cruzada reformista abolicionista para uma política nacional abolicionista", ${ }^{33}$ por meio da qual os abolicionistas britânicos podiam contar com certa proteção do estado britânico em suas ações, quer através da diplomacia quer através da força efetiva, como ocorreu em certas situações, principalmente na África.

Contudo, é necessário destacar um ponto inclusive muito salientado pelo movimento abolicionista britânico: o medo de que as atividades abolicionistas resultassem na rebelião de escravos e, consequentemente, no assassinato dos senhores, na subversão da ordem e no derramamento de sangue. Ainda que esporadicamente alguns grupos abolicionistas jogassem politicamente com a possibilidade de mobilização dos escravos, em geral, o sentimento abolicionista britânico estremecia quando se deparava com a possibilidade de uma revolta sangrenta. ${ }^{44}$

Paralelamente, ou até mesmo imbricado à ofensiva abolicionista, a Grã-Bretanha também conheceu o crescimento do movimento missionário no início do século XIX. Segundo a definição de C. Duncan Rice, "a relação entre

\footnotetext{
${ }^{42}$ Para uma apreciação desse intercâmbio, ver FROST, J. William. Introduction. In: FROST, J. William (ed.). The Quaker origins of antislavery. Norwood: Norwood Editions, 1980, p. 1-30; ver ainda o estudo pioneiro de ABEL, Annie Heloise \& KLINGBERG, Frank J. A side-light on Anglo-American relations. 1839-1858. Nova York: Augustus M. Kelley, 1970 [original de 1927]; FLADELAND, Betty. Men and brothers. Anglo-American antislavery cooperation. Urbana: University of Illinois Press, 1972; para o período posterior ao abordado neste trabalho, ver a correspondência dos garrisonianos, de ambos os lados do Atlântico, em TAYLOR, Clare, op. cit.

${ }^{43}$ HUZZEY, Richard. Freedom burning. Anti-slavery and empire in Victorian Britain. Ithaca: Cornell University Press, 2012, p. 40.

${ }^{44}$ HUZZEY, Richard, op. cit., p. 29, 68.
} 
os dois movimentos era genuinamente simbiótica", 45 e pode ser facilmente atestada pelo impacto que a morte do missionário Smith em Demerara, em 1824, e a prisão do missionário Knibb na Jamaica, em 1832, causaram ao movimento abolicionista britânico - facilitando inclusive a aprovação da lei de emancipação, em 1833. Do mesmo modo, pode-se entender o fervor religioso e abolicionista que a criação da colônia de Serra Leoa e a expedição de Buxton ao Níger despertaram nos dois movimentos.

Todavia, é preciso deixar claro que, nas sociedades escravistas das Américas, mesmo os missionários religiosos não exerceram uma postura abertamente abolicionista, com vistas a minar os fundamentos escravistas dessas sociedades por meio de uma atuação política direta, concreta e panfletária. Ainda que em seus cultos condenassem a escravidão e as atitudes dos senhores, sua militância abolicionista encontrava limites em suas próprias atividades religiosas, que eram severamente vigiadas pelos senhores e autoridades locais. ${ }^{46}$

Ao que tudo indica, a primeira vez que se organizou claramente uma missão abolicionista às Américas, com o intuito deliberado de promover a causa do fim da escravidão, foi em 1834, com a missão de George Thompson ao norte dos Estados Unidos. Thompson era um abolicionista britânico que se tornou amigo do abolicionista norte-americano William Lloyd Garrison, quando este viajou para a Grã-Bretanha em 1833. Atendendo ao convite do anfitrião norte-americano, Thompson arrecadou dinheiro junto às hostes do movimento abolicionista britânico e partiu para o norte dos Estados Unidos com a missão de realizar palestras abolicionistas.

Todavia, Thompson teve uma recepção extremamente desagradável, foi inclusive apedrejado em Lowell, sofreu perseguição das hordas pró-escravistas em Boston e teve que se retirar do hotel em que estava hospedado em Nova York. Enfim, após um ano no norte dos Estados Unidos, teve que fugir clandestinamente num navio. ${ }^{47}$

Quando consideramos o exemplo de George Thompson, cujas palestras foram realizadas no norte dos Estados Unidos, o caráter secreto da missão dos Pilkington ao Brasil não causa surpresa. Diante dos objetivos estipulados no documento "Missão nos Brasis", o casal de agentes correria sérios riscos

\footnotetext{
${ }^{45}$ RICE, C. Duncan. The missionary context of the British anti-slavery movement. In: WALVIN, James (ed.) Slavery and British society, 1776-1846. Londres; Basingstoke: The Macmillan Press Ltd, 1982, p. 150.

${ }^{46}$ Cf. COSTA, Emilia Viotti da. Coroas de glória, lágrimas de sangue. A rebelião dos escravos em Demerara em 1823. São Paulo: Companhia das Letras, 1998.

${ }^{47}$ Cf. TEMPERLEY, Howard. British antislavery, op. cit., p. 27.
} 
caso suas intenções fossem descobertas, ainda que todas as instruções possuíssem um caráter eminentemente pacífico. Aliás, numa de suas primeiras cartas à BFASS, o próprio Pilkington externava claramente o seu medo ao constatar a ubiquidade do sistema escravista brasileiro:

\begin{abstract}
Quando escrevi minha última carta, expressei todo o embaraço de um espírito sincero diante de um empreendimento perigoso e, ao mesmo tempo, aparentemente paralisado por todas as perspectivas de sua realização; porque, ao contrário das nações escravistas, não parece haver qualquer simpatia, em qualquer classe, quer entre as pessoas de cor livres, entre os brasileiros ou os colonos ingleses. Na classe dos homens de cor livres, porque não estão tão seguros de desfrutar de todos os privilégios que são concedidos pela Lei às demais. Embora, individualmente, sejam tão respeitados como se fossem brancos; portanto, não têm nada a ganhar ao favorecer o escravo. Na classe dos brasileiros, porque se mantêm distantes dos estrangeiros, em parte, devido a certo grau de orgulho, para dissimular sua pobreza. Na classe dos colonos ingleses, porque eles são geralmente tão contaminados pelo sistema que, na maior parte dos casos, são os próprios proprietários de escravos; e, em todos os casos, os seus rendimentos dependem do trabalho dos escravos nacionais. ${ }^{48}$
\end{abstract}

Ou seja, a solidariedade dos grupos abolicionistas organizados e dos simpatizantes da causa, com a qual Thompson ainda pôde contar no norte dos Estados Unidos, não existia no Brasil. Pilkington não via nenhum grupo ao qual pudesse se aproximar, pois todos estavam envolvidos diretamente com a escravidão ou não aufeririam nenhum benefício ao combatê-la. Com efeito, o medo da BFASS e o seu próprio de que seus objetivos e sua identidade fossem descobertos não eram infundados.

\title{
O panorama brasileiro e a atuação dos Pilkington
}

Em primeiro lugar, é preciso lembrar que a principal atribuição do casal Pilkington referia-se à coleta de informações precisas - "todos os demais princípios devem estar subordinados a este" - conforme especificava o documento. Somente após a obtenção dessas informações, uma atuação mais direta poderia ser empreendida. Mesmo assim, essa atuação deveria ser extremamente discreta, e se limitar a estabelecer correspondentes com a BFASS e eventuais representantes brasileiros ao Congresso Abolicionista Mundial.

\footnotetext{
${ }^{48}$ Carta de George Pilkington, 25/03/1840. In: MSS. Brit. Emp. s. 22, G.79.
} 
Observando-se as informações disponíveis a respeito da movimentação do casal, percebe-se que ambos tiveram poucas oportunidades de empreender qualquer atividade abolicionista mais sistemática. Charlotte, por exemplo, permaneceu durante toda a estada no Rio de Janeiro e seus arredores coletando informações junto a ingleses que compartilhavam a amizade de seus anfitriões. Numa sociedade como a do Rio de Janeiro de meados do século XIX, certamente uma mulher não encontraria espaços sociais para qualquer atuação abolicionista mais direta. Em relação a Pilkington, de meados de fevereiro de 1840 até junho do mesmo ano, não se tem notícias de que tenha realizado atividades fora do Rio de Janeiro. Todavia, em junho, ele empreendeu uma viagem a Minas Gerais para investigar especificamente a condição dos escravos das minas inglesas. Em 11 de agosto, retornou ao Rio, conforme ele próprio relatou a Joseph Sturge numa carta de 7 de setembro de 1840. A seguir, provavelmente neste mesmo mês, partiu numa viagem rumo ao Pará, costeando o litoral norte brasileiro. No início de novembro, ainda não havia retornado ao Rio e Charlotte informava a Sturge que Pilkington dificilmente deixaria o Brasil sem visitar a província de São Paulo.

Todo esse périplo indica que Pilkington não dispôs de tempo suficiente para desenvolver qualquer atividade abolicionista que demandasse uma organização mais efetiva. Seguramente, nessas viagens, sua preocupação consistia em obter informações corretas. Eventualmente, ele pode ter organizado alguma palestra, não necessariamente ligada à escravidão, já que antes de aderir ao movimento abolicionista, Pilkington era um pregador pacifista na Grã-Bretanha. ${ }^{49}$ Após retornar do Pará, Pilkington, então, se dedicou à elaboração dos panfletos, lançados no Rio de Janeiro no início de 1841. Esta última atividade não estava prevista no documento "Missão nos Brasis", embora fosse assunto de uma de suas cartas, como foi salientado por David Eltis.

Já em relação ao cenário brasileiro, o período em que George e Charlotte Pilkington permaneceram no Brasil foi muito conturbado politicamente. As divergências a respeito da maioridade do imperador, decretada na sessão de 23 de julho de 1840, as trocas de gabinete e as revoltas, principalmente, a Balaiada, no Maranhão, e a Farroupilha, no Rio Grande do Sul, agitavam

\footnotetext{
${ }^{49}$ Em seu panfleto Epístola aos ingleses..., Pilkington afirma que presidiu reuniões em várias províncias do Brasil para tratar da propagação dos princípios da paz. Cf. PILKINGTON, George. Epístola aos ingleses residentes no Império do Brasil. Rio de Janeiro: Typographia de Laemmert, 1841, p. 4. Infelizmente, considerando as dimensões deste artigo, é impossível traçar um panorama da trajetória de vida e das atividades pregressas de George Pilkington.
} 
rev. hist. (São Paulo), n. 174, p. 69-100, jan.-jun., 2016 http://dx.doi.org/10.11606/issn.2316-9141.rh.2016.115377
Henrique Antonio Ré

"Missão nos Brasis": a BFASS e a organizaç̃óo de uma missão abolicionista secreta ao Brasil no ińício da década de 1840

o Império e ameaçavam despedaçá-lo. Somem-se a elas, as revoltas de escravos, principalmente a dos malês, em 1835 na Bahia, que atemorizou os senhores e autoridades de todo o país. Apesar dessa agitação, o Brasil estava assumindo sua posição na economia mundial como principal produtor e exportador de café, cultura desenvolvida eminentemente por meio do trabalho escravo, obtido graças ao tráfico ilegal.

E o tráfico ilegal de escravos, mais do que a própria escravidão, era uma das questões mais candentes no Brasil durante as décadas de 1830 e 1840. Por um lado, havia a necessidade de mão-de-obra escrava para atender ao crescimento das lavouras de café, que, por sua vez, respondiam à demanda do Atlântico norte por produtos de plantation. Por outro lado, contraditoriamente, havia entre os políticos e publicistas brasileiros o medo da africanização do país e da possibilidade de que uma revolta semelhante à ocorrida em Saint-Domingue pudesse se repetir; somada a esses medos, a crescente pressão britânica contra o tráfico ilegal de escravos, materializada nos constantes aprisionamentos de navios, impunha que se tomassem medidas para combatê-lo. ${ }^{50}$

O casal Pilkington soube captar os principais elementos dessa tensão e transmiti-los aos seus superiores da BFASS. Por meio de uma matéria publicada no Anti-Slavery Reporter, intitulada "Brasil", e composta com informações transmitidas por George Pilkington, os abolicionistas britânicos tomavam conhecimento de que o ministério liberal brasileiro havia caído:

Lamento afirmar que o ministério caiu. O atual fará uma administração pró-escravista. Quanto à suspensão do tráfico com medidas claras e ousadas, como as que estavam sendo tomadas, o novo ministério já desfez tudo que os seus predecessores tinham se esforçado para fazer. Nosso governo deve ser bastante cauteloso se for celebrar um novo tratado com o Brasil. Além disso, não deve insistir na aplicação do antigo tratado no que diz respeito à entrega para as autoridades britânicas de todos os negros con-

\footnotetext{
${ }_{50}$ Sobre o final do tráfico no Brasil, ver o estudo de BETHELL, Leslie. A abolição do tráfico de escravos no Brasil. Grã-Bretanha, o Brasil e a questão do tráfico de escravos, 1807-1869. Rio de Janeiro: Expressão e Cultura, 1976. Já o panorama ideológico a respeito da questão do tráfico nas décadas de 1830-40 foi tomado de RODRIGUES, Jaime. O infame comércio. Propostas e experiências no final do tráfico de africanos para o Brasil (1800-1850). Campinas: Editora da Unicamp/Cecult, 2000, especialmente capítulos 1 e 2.
} 
rev. hist. (São Paulo), n. 174, p. 69-100, jan.-jun., 2016 http://dx.doi.org/10.11606/issn.2316-9141.rh.2016.115377
Henrique Antonio Ré

"Missão nos Brasis": a BFASS e a organização de uma missão abolicionista secreta ao Brasil no início da década de 1840

trabandeados e aqui desembarcados desde o início da sua vigência, muitos dos quais estão em mãos de autoridades brasileiras como suas incontestáveis propriedades! ${ }^{51}$

Para os abolicionistas britânicos, mais importante do que a queda do ministério brasileiro era a forma como os gabinetes que se revezavam no poder combatiam ou incentivavam o tráfico de escravos. Pilkington expressava claramente que o novo ministério conservador, além de pró-escravista, estava desarticulando as medidas que o ministério anterior implementara para combater o tráfico de escravos. Por meio dessa notícia, os abolicionistas britânicos tinham condições de avaliar não somente as ações do governo brasileiro relativas ao tráfico, mas mapear quais grupos ou indivíduos poderiam ser considerados como aliados ou inimigos da causa. ${ }^{52}$

O final da notícia ainda estampava uma das grandes preocupações dos abolicionistas britânicos: o destino dos "africanos livres" tomados aos traficantes pelos navios do esquadrão britânico ou pelos agentes brasileiros.

Charlotte, numa carta de 1840, também já havia chamado a atenção dos dirigentes da BFASS para os estratagemas utilizados para reescravizar os "africanos livres". Segundo ela, esses africanos eram entregues a pessoas que possuíam influência junto às autoridades. Como não havia um registro confiável dos escravos e dos africanos livres, quando um escravo falecia, atribuía-se a morte a um "africano livre". Deste modo, este último tornava-se, de fato, um escravo:

Mas, para voltar à situação efetiva destes infelizes aprendizes, que não difere no menor grau da de um escravo comprado regularmente, é notório que quando morre qualquer

\footnotetext{
${ }^{51}$ Anti-Slavery Reporter, 16 de junho de 1841, p. 131. Pilkington se refere à queda do primeiro ministério do Segundo Reinado, encabeçado por Antônio Carlos Ribeiro de Andrada Machado e Silva, que ocorreu nos fins de maio de 1841.

52 A partir dos estudos de David Eltis sobre o tráfico de escravos, a historiografia contemporânea comprovou estatisticamente aquilo que o casal de abolicionistas já havia informado aos seus pares britânicos. Ver a tabela de Eltis sobre as importações de escravos para o Brasil, que estampa claramente os efeitos da repressão brasileira ao tráfico. As maiores quedas ocorreram entre 1831-33, por ocasião da entrada em vigor do tratado entre o Brasil e a Inglaterra e da lei brasileira, de 1831, contra o tráfico de escravos. Outro momento de queda acentuada ocorreu na passagem de 1840-41, em decorrência do esforço do gabinete liberal, tal como salientado por Pilkington. Cf. ELTIS, David. Economic growth and the end of the transatlantic slave trade, op. cit., p. 244. Mais recentemente, Tâmis Parron, ao estudar aquilo que denominou de política da escravidão, também demonstrou que a lei de 1831, ao contrário de sua alcunha - lei para inglês ver - representou um esforço significativo na repressão do tráfico. Este estudo também expôs detalhadamente as diferenças de postura entre os gabinetes liberais e os conservadores em relação à repressão ao tráfico de escravos. Cf. PARRON, Tâmis. A política da escravidão no Império do Brasil. 1826-1865. Rio de Janeiro: Civilização Brasileira, 2011, principalmente capítulos 1 e 2.
} 
rev. hist. (São Paulo), n. 174, p. 69-100, jan.-jun., 2016 http://dx.doi.org/10.11606/issn.2316-9141.rh.2016.115377
Henrique Antonio Ré

"Missão nos Brasis": a BFASS e a organizaç̃ão de uma missão abolicionista secreta ao Brasil no início da década de 1840

escravo pertencente aos partidários que possuem estes aprendizes, considera-se que quem morreu foi um aprendiz. (Isto quando não ocorre de cadáveres serem comprados com este propósito). A partir de então, ele é substituído pelo escravo morto, e daí em diante torna-se propriedade indiscutível do titular e de seus herdeiros! É claro que se se tratar de uma mulher, a escravidão recairá também sobre sua descendência. ${ }^{53}$ Grifos da autora.

Charlotte ainda descobriu que muitas pessoas que recebiam esses "africanos livres" possuíam ações nos empreendimentos negreiros capturados. Portanto, a redistribuição dos africanos era uma forma de minimizar as perdas decorrentes das apreensões. ${ }^{54}$

As contradições entre, de um lado, o medo da africanização e da haitianização do Brasil e, de outro, a adoção dos estratagemas mais variados para a continuidade do tráfico já podem ser rastreadas desde a lei brasileira de 1831 que proibiu o tráfico de escravos. Embora tenha sido burlada durante quase vinte anos, inclusive pelos próprios representantes do governo - que várias vezes tentaram revogá-la -, ela determinava em seu artigo $2^{\circ}$ que o governo cuidasse que a reexportação dos africanos ilegais se fizesse "efetiva com a maior brevidade possível".55

A tentativa de reexportação dos africanos introduzidos ilegalmente no país não vingou, mas, depois das rebeliões escravas na Bahia na década de 1830 , alguns políticos e publicistas passaram a defender a reexportação da "raça bárbara" para a África, tão logo esses indivíduos conquistassem a liberdade. ${ }^{56}$ Note-se que não se pregava a reexportação de todos os escravos importados ilegalmente, mas somente a dos negros que, porventura, conquistaram a liberdade.

\footnotetext{
${ }^{53}$ Carta de 23/09/1840. In: MSS. Brit. Emp. s. 22, G.79. Há uma imprecisão terminológica de Charlotte, pois não houve no Brasil a categoria "aprendiz". Essa categoria foi criada para as Índias Ocidentais britânicas. Como a emancipação nas colônias britânicas do Caribe não foi imediata, antes dos escravos serem considerados livres, eles deveriam passar por um período de aprendizado, que variava conforme sua ocupação, para que pudessem assimilar seus deveres de cidadãos e aprendessem a utilizar a liberdade que lhes seria concedida. A experiência não foi bem sucedida e o "aprendizado" foi abolido antes do prazo estipulado. No Brasil, os africanos apreendidos dos traficantes eram considerados como livres, embora, como podemos ver pelo relato de Charlotte, viviam em condições semelhantes às dos escravos. Em 1853, Nabuco de Araújo, então ministro da Justiça, lançou um decreto ordenando que "os africanos livres, que tiverem prestado serviços a particulares pelo espaço de 14 anos, sejam emancipados quando o requeiram". Obviamente, tal dispositivo, na prática, era extremamente ineficaz. Cf. Decreto 1.303, de 28 de dezembro de 1853. In: Coleção de Leis do Império do Brasil, 1853, v. 1, pt. II, p. 420.

${ }^{54}$ Idem.

${ }^{55}$ MOURA, Clóvis. Dicionário da escravidão negra no Brasil. São Paulo: Edusp, 2004, p. 240.

${ }^{56}$ Cf. RODRIGUES, Jaime, op. cit., p. 88-9.
} 
Todavia, nem sempre os planos funcionavam de acordo com o previsto. Uma notícia transmitida por Charlotte deve ter desagrado demais aos abolicionistas britânicos, num prenúncio do que seria o desastre de seus planos de colonização da África. Seguramente, tal evento também deve ter sido repudiado por aqueles brasileiros que defendiam a reexportação dos africanos que obtinham alforria. Em seus planos, ambos os grupos sempre consideravam o escravo ou o africano como sujeitos passivos, suscetíveis de serem dominados e conduzidos. Entretanto, a notícia de Charlotte coloca em xeque essa suposição:

O poderoso argumento em favor da proposta de Fowell Buxton ${ }^{57}$ em relação à África parecia forçosamente viciado em minha mente enquanto ouvia o seguinte relato da boca de um informante que merece crédito. Este indivíduo afirmou que cerca de 400 negros livres, que haviam obtido sua liberdade pelo produto de sua indústria enquanto eram escravos, fretaram um navio para levá-los de volta ao seu país. Contudo, ao retornarem, acharam que seria muito difícil ali permanecerem devido ao seu gosto atual e seus hábitos mais refinados. Com pouquíssimas exceções, acharam melhor regressar ao Brasil, afirmando em seu retorno que não poderiam conviver com negros. ${ }^{58}$

Embora esta notícia careça de precisão e não apresente maiores detalhes do episódio, ela tem o mérito de indiretamente dar voz àqueles ex-escravos. E, ao fazê-lo, indica que não se tratava de sujeitos passivos. Ao contrário, por terem conquistado a alforria "pelo produto de sua indústria" já demonstraram querer transpor os limites sociais que lhes eram impostos; ao se recusarem a permanecer na África, num ambiente que lhes desagradava, demonstraram a prevalência de sua vontade sobre quaisquer outras determinações. Enfim, apresentaram-se como sujeitos dispostos a lutar pelo lugar social ao qual acreditavam ter direito.

No fundo, esses exemplos ilustram a grande contradição que permeou a bacia do Atlântico durante a maior parte do século XIX: a relação entre crescimento econômico e combate ao trabalho coercitivo. A mesma matriz econômica e ideológica que propiciou o desenvolvimento econômico e industrial do

\footnotetext{
57 Thomas Fowell Buxton (1786-1845), abolicionista britânico, membro do parlamento, que em 1839 formou a Society for the Extinction of the Slave Trade and for the Civilization of Africa. Em 1841, essa sociedade organizou uma expedição ao rio Níger com o objetivo de estabelecer colônias agrícolas para servir de modelos aos povos africanos, incentivando-os desse modo a adotar o trabalho livre e o comércio legítimo ao mesmo tempo em que deveriam abandonar o tráfico de escravos. A expedição, assolada, provavelmente, pela malária, foi um fracasso terrível, resultando na morte de inúmeras pessoas.

${ }^{58}$ Carta de 24/02/1840, MSS. Brit. Emp. s. 22, G.79.
} 
Atlântico norte, desenvolvimento que se beneficiou enormemente dos produtos de plantation e do trabalho escravo, tornou-se também o ponto de partida do pensamento e das ações abolicionistas. Por um lado, três regiões econômicas se beneficiando do sistema escravista: os países europeus do Atlântico norte, as sociedades escravistas das Américas e as regiões africanas exportadoras de escravos; por outro, ações abolicionistas nessas mesmas regiões visando reprimir e finalmente eliminar o tráfico e a escravidão. ${ }^{59}$ No momento em que o casal Pilkington visitou o Brasil, a questão do tráfico de escravos, mutatis mutandis, era a que melhor expressava tal contradição no âmbito local.

Enfim, considerando a natureza da missão e as condições brasileiras da década de 1840, George e Charlotte Pilkington parecem ter correspondido aos propósitos pelos quais foram enviados ao Brasil. Suas informações detalhadas sobre o tráfico de escravos e a escravidão foram publicadas pelo Anti-Slavery Reporter durante praticamente todo o ano de 1841. E, a partir de então, a BFASS possuía informações relativamente precisas sobre a situação brasileira, que lhe permitiam se situar com mais segurança no debate político britânico acerca das ações abolicionistas implementadas pelo Império abolicionista. ${ }^{60}$

\section{Apêndice}

\section{Missão nos Brasis}

A importância da pretendida missão nos Brasis certamente não pode ser subestimada. Para que ela seja bem-sucedida haverá necessidade de muita sagacidade, energia e prudência. O Comitê tem muita confiança na inteligência, no zelo e na retidão do caráter dos seus amigos - George Pilkington e sua esposa. Mas, considerando a sua própria posição, a causa que representa e a segurança pessoal dos amigos, o Comitê sente-se na obrigação de sugerir algumas cautelas que as circunstâncias deste caso parecem exigir para que eles realizem um trabalho que assumiram livremente:

1 - Em primeiro lugar, o Comitê se sente no dever de aconselhar seus amigos a irem aos Brasis como se fossem simplesmente viajantes. Desse modo, não

\footnotetext{
${ }^{59}$ Esse quadro é tomado de ELTIS, David. Economic growth and the end of the transatlantic slave trade, especialmente capítulos 3 e 4 e, mais genericamente, de DRESCHER, Seymour. Capitalism and antislavery. British mobilization in comparative perspective. Nova York; Oxford: Oxford University Press, 1987, especialmente capítulo 1.

${ }^{60}$ A expressão "Império abolicionista" foi tomada de HUZZEY, Richard, op. cit., p. 177.
} 
criariam suspeitas e poderiam coletar informações, entre outras coisas, sobre matérias-primas produzidas no Império, isto é, sobre açúcar, algodão, café etc. Sobre as regiões em que são produzidas, especialmente o algodão comercial, seus diferentes tipos, suas formas de cultivo e de preparação para o mercado. Poderiam também obter informações sobre as estatísticas do Império referentes à população e aos produtos, sobre exportação e importação, sobre os artigos mais procurados pela população local e pelo comércio estrangeiro. Poderiam também averiguar se a imigração europeia será promovida pelas autoridades, quais são as melhores regiões para a formação de colônias e qual será a natureza das vantagens que o governo oferecerá e que proteção ele concederá aos que chegarem ao país.

Poderiam ainda verificar o número de índios no país, os seus hábitos, o estado de civilização em que se encontram e se são protegidos ou não. Esses e outros pontos que poderão aparecer estão intimamente ligados com a nossa causa e o bem-estar geral da humanidade; sendo assim, são assuntos legítimos de investigação em conexão com os quais talvez se possa obter prontamente informação a respeito de pontos específicos sobre os quais o Comitê deseja expressamente. 2-Em segundolugar, o Comitêsugerequevocês não divulguem em ocasião alguma, enem a qualquer pessoa com a qual seus amigos possam vir a ter contato, suas conexões com esta instituição, ou qual é o objetivo particular da visita aos Brasis.

O Comitê considera que essa regra é inviolável e, caso haja quebra de sigilo, suas vidas poderão estar em risco ou, pelo menos, serão frustradas suas tentativas de obter informações e serão obrigados a deixar o país.

Depois que tiverem em mãos as informações requisitadas e apurarem a extensão do sentimento abolicionista e do desejo honesto existente dentro da comunidade brasileira para pôr fim ao tráfico negreiro e à escravidão, haverá tempo suficiente para sugerir a formação de sociedades com este fim e para atrair correspondentes que possam se comunicar confidencial ou abertamente com o Comitê. Por mais desejável que seja contar com representantes dos Brasis no Congresso Abolicionista de 1840, deve ser lembrado que a obtenção de informação correta é de importância primordial - e, de fato, todos os demais princípios devem estar subordinados a este.

3 - O Comitê pediria seriamente aos seus amigos que, quando houver imprevistos e não for possível ter certeza quanto ao rumo exato a ser seguido, que eles não esmoreçam, aconselhando-se um com o outro se for possível, e que de forma alguma corram riscos. 
Sobre esse ponto, o Comitê deve contar com a discrição dos seus amigos e confiar que estarão tão vigilantes e concentrados que se protegerão contra erros de julgamento e imprudência na ação.

4 - O Comitê recomenda também que seus amigos não deverão levar para os Brasis quaisquer publicações abolicionistas, exceto as que sejam importantes para o conhecimento de pontos para os quais suas atenções deverão estar especialmente dirigidas; mesmo assim, elas deverão ser usadas durante a viagem e ser destruídas antes do desembarque.

O Comitê entende também que quaisquer cartas de apresentação que sejam necessárias devem ser meramente recomendatórias dos seus amigos às boas graças das pessoas para as quais elas são dirigidas. Os livros a serem usados como guias nos Brasis podem evidentemente ser mantidos.

Finalmente, o Comitê considera que o seu objetivo poderá ser alcançado da forma sugerida, e que se os nossos amigos mantiverem os olhos abertos e os cuidados necessários - e ele não tem dúvida alguma de que farão isso - e, se tirarem proveito das oportunidades fortuitas para conseguir a informação desejada, poderá ser obtido um corpo valioso de fatos e detalhes que promoverá um grande avanço no objetivo que o Comitê tem em vista e assim atingirá o fim para o qual a missão foi empreendida.

\section{J. H. Tredgold ${ }^{61}$}

\section{Referências bibliográficas Fontes primárias Arquivo}

Rhodes House Library, Oxford, file G 79, British Empire MSS, S. 22.

Periódicos

Anti-Slavery Reporter. Editado pela British and Foreign Anti-Slavery Society.

\section{Outros materiais}

A Chronological Summary of the work of the British \& Foreign Anti-Slavery Society during the nineteenth century (1839-1900). Londres: Offices of the Society, 1901.

\footnotetext{
${ }^{61}$ TREDGOLD,J.H.Mission to Brazils.s. d.Rhodes HouseLibrary, Oxford, FileG79, British Empire, mss., s. 22.
} 
British and Foreign Anti-Slavery Society for the Abolition of Slavery and SlaveTrade throughout the World. Adress. Londres: Johnston and Barret, [1839?]. Londres: John Murray, 1840.

CLARKSON, Thomas. History of the rise, progress, and accomplishment of the abolition of the African slave trade by the British Parliament. $1^{\text {a }}$ edição. Londres: Longman, 1808, 2 vol.

COLEÇÃO de Leis do Império do Brasil.

PILKINGTON, George. Epístola aos ingleses residentes no Império do Brasil. Rio de Janeiro: Typographia de Laemmert, 1841.

PILKINGTON, George. Extratos dos discursos de John Scoble e a carta duodécima de Joseph Gurney acerca das vantagens obtidas com a emancipação dos escravos nas colônias britânicas, recopilados por George Pilkington. Rio de Janeiro: Typographia de Laemmert, 1841.

PILKINGTON, George. Réplica de Jorge Pilkington a um padre no Brasil que em uma carta lhe mostrava um ardente desejo de que ele abraçasse as opiniões católicas romanas sobre a verdade religiosa. Rio de Janeiro: Typographia de Laemmert, 1841.

Proceedings of the General Anti-Slavery Convention, called by the Committee of the British and Foreign Anti-Slavery Society and held in London, from Friday, June $12^{\text {th }}$ to Tuesday, June $23^{\text {rd }}$ 1840. Londres: British and Foreign Anti-Slavery Society, 1841.

Proceedings of the General Anti-Slavery Convention, called by the Committee of the British and Foreign Anti-Slavery Society and held in London, from Tuesday, June $13^{\text {th }}$ to Tuesday, June $20^{\text {th }}$ 1843. Londres: British and Foreign Anti-Slavery Society, 1843.

Revista do Instituto Historico e Geographico do Brazil, t. 1, n. 3 (3o sem. 1839). Rio de Janeiro: Imprensa Nacional, 1908.

SILVA, José Bonifácio de Andrada e. Representação à Assemblea Geral Constituinte e Legislativa do Império do Brasil, sobre a escravatura. Por José Bonifácio de Andrada e Silva, deputado à dita Assemblea pela Provincia de S. Paulo. Rio de Janeiro: Typographia de J. E. S. Cabral, 1840.

The Third Annual Report of the British and Foreign Anti-Slavery Society for the Abolition of Slavery and the Slave-Trade throughout the World; presented to the General Meeting held in Exeter Hall, on Friday, May 13 ${ }^{\text {th }}$, 1842. Londres: Printed for the Society, 1842.

TURNBULL, David. Travels in the West: Cuba; with notices of Porto Rico and the slave trade. Londres: Longman, Orme, Brown, Green, and Longmans, 1840.

\section{Historiografia}

ABEL, Annie Heloise $\mathcal{E}$ KLINGBERG, Frank J. A side-light on Anglo-American relations. 1839-1858. Nova York: Augustus M. Kelley, 1970 [original de 1927].

BETHELL, Leslie. A abolição do tráfico de escravos no Brasil. Grã-Bretanha, o Brasil e a questão do tráfico de escravos, 1807-1869. Rio de Janeiro: Expressão e Cultura, 1976.

BETHELL, Leslie $\&$ CARVALHO, José Murilo de (org.). Joaquim Nabuco e os abolicionistas britânicos. Correspondência, 1880-1905. Rio de Janeiro: Topbooks, 2008.

COSTA, Emilia Viotti da. Coroas de glória, lágrimas de sangue. A rebelião dos escravos em Demerara em 1823. São Paulo: Companhia das Letras, 1998.

DRESCHER, Seymour. Capitalism and antislavery. British mobilization in comparative perspective. Nova York; Oxford: Oxford University Press, 1987. 
ELTIS, David. Economic growth and the end of the transatlantic slave trade. Nova York: Oxford University Press, 1989.

FLADELAND, Betty. Men and brothers. Anglo-American antislavery cooperation. Urbana: University of Illinois Press, 1972.

FROST, J. William. Introduction. In FROST, J. William (ed.). The Quaker origins of antislavery. Norwood: Norwood Editions, 1980.

GALLAGHER, J. Fowell Buxton and the New African Policy, 1838-1842. Cambridge Historical Journal, v. 10, n. 1, 1950, p. 36-58.

HARRIS, John. A century of emancipation. Londres: Kennikat Press, 1971.

HUZZEY, Richard. Freedom burning. Anti-slavery and Empire in Victorian Britain. Ithaca: Cornell University Press, 2012.

MARSHALL, Oliver. Brazil in British and Irish archives. $2^{\text {a }}$ edição. Oxford: Centre for Brazilian Studies. University of Oxford, 2007.

MOURA, Clóvis. Dicionário da escravidão negra no Brasil. São Paulo: Edusp, 2004.

MURRAY, David. Odious commerce. Britain, Spain and the abolition of the Cuban slave trade. Cambridge: Cambridge University Press, 1980.

PARRON, Tâmis. A política da escravidão no Império do Brasil. 1826-1865. Rio de Janeiro: Civilização Brasileira, 2011.

RICE, C. Duncan. The missionary context of the British anti-slavery movement. In: WALVIN, James (ed.). Slavery and British society, 1776-1846. Londres; Basingstoke: The Macmillan Press Ltd, 1982.

RODRIGUES, Jaime. O infame comércio. Propostas e experiências no final do tráfico de africanos para o Brasil (1800-1850). Campinas: Editora da Unicamp/Cecult, 2000.

TAYLOR, Clare. British and American abolitionists. Edinburgh: Edinburgh University Press, 1974.

TEMPERLEY, Howard. British antislavery, 1833-1870. Columbia: University of South Carolina Press, 1972.

TEMPERLEY, Howard. White dreams, black Africa. The antislavery expedition to the river Niger, 1841-1842. New Haven; Londres: Yale University Press, 1991.

TOMICH, Dale. Pelo prisma da escravidão. Trabalho, capital e economia mundial. São Paulo: Edusp, 2011. 